\title{
Crafting Local Institution Using Social-Ecological System Framework for Sustainable Rattan Governance in Lore Lindu National Park
}

\author{
Yulianto $^{1}$, Rinekso Soekmadi ${ }^{2 *}$, Agus Hikmat ${ }^{3}$, Cecep Kusmana ${ }^{4}$ \\ ${ }^{1}$ Graduate Program of Tropical Biodiversity and Conservation, Faculty of Forestry, IPB University (Bogor Agricultural \\ University), Dramaga Campus, Bogor, Indonesia 16680 \\ ${ }^{2}$ Department of Forest Resource Conservation and Ecotourism, Faculty of Forestry, IPB University (Bogor Agricultural \\ University), Dramaga Campus, Bogor, Indonesia 16680
}

${ }^{3}$ Department of Silviculture, Faculty of Forestry, IPB University (Bogor Agricultural University), Dramaga Campus, Bogor, Indonesia 16680

Received September 16, 2019/Accepted October 31, 2019

\begin{abstract}
Rattan is the most important non-forest timber product utilized by communities adjacent Lore Lindu National Park (LLNP). The establishment community conservation agreement (CCA) in 2001 was unable to prevent rattan depletion. Then, a local institution called community conservation partnership (CCP) has been recently proposed. Therefore, the objective of this study is to explore how to craft a local institution of CCP for sustainable rattan governance in LLNP using Social-Ecological Systems (SES) Framework. The study was conducted in LLNP area and Ngata Toro, a buffer zone village of LLNP. We conducted rattan inventory and collected social data by interview for analyzing CCP development using SES framework. The results showed that CCP is most likely to be successful in implementing due to several reasons. Firstly, the establishment of constitutional-choice rules made clear the nested enterprise. Secondly, the reallocation of CCP location to the traditional zone increase the boundary clarity. Thirdly, transferring rights to the Ngata Toro community will make effective co-management, increase the legitimacy of rattan utilization, decrease potential conflicts among resource unit users and reducing monitoring cost. Finally, deciding the rattan harvesting quota will ensure the rattan ecological and livelihood sustainability. With the clarity of system boundaries and property rights, we argue that CCP institutions will bring many benefits in many ways. Overall, most variables of SES framework can be used to analyses the readiness of CCP institutional arrangement for sustainable rattan management in LLNP.
\end{abstract}

Keywords: co-management, institution, non-timber forest product, community, sustainability

*Corresponding author, email: r.soekmadi@yahoo.co.id

\section{Introduction}

Utilizing non-timber forest products (NTFs) is generally giving less ecological impacts compared to timber harvesting and wildlife hunting in a conservation area. Harvesting of high valuable NTFS has been considered a win-win strategy where local communities gain profits while conserving forest biodiversity and ecosystem services (Barrios et al., 2014). The most important NTFPs for local communities adjacent Lore Lindu National Park (LLNP) is the rattan. It has been utilized for both subsistence and commercial purposes. Rattan in LLNP is common-pool resources (CPRs) that characterized by their rivalry and non-excludable characters. Within a single common-pool resource situation, a conglomeration of de jure and de facto property rights may exist, which overlap, complement, or even conflict with one another (Schlager \& Ostrom, 1992). It is commonly found that many rattan plants exist in many customary lands, which overlapping not only with LLNP area but also among other customary lands. The customary lands were decided based on communities' claim, for instance, Ngata Toro community leaders claimed that the customary land (tanah adat) is 22,950 ha of secondary and primary forest in which 18,000 ha of the area within the LLNP (Burkard, 2007). Despite this, many local communities have regulated utilization rattan and other resources of their customary land, but for overlapping claimed land properties in LLNP area have several weaknesses. Firstly, property rights and clarity of system boundaries are undefined clearly. Secondly, the unclear boundary among different customary lands made less legitimate, therefore, many harvesters have crossed to customary neighbor areas. Thirdly, LLNP previously not accommodated harvesting rattan for local communities because no specific guiding regulations for operational choice-rules, collective choice rules, and constitutionalchoice rules were completely established. Fourthly, local communities did have a scientific method to decide the amount of sustainable rattan harvesting.

Rattan in LLNP area is state property, and factually, it 
tends to open access. In this dual institutional reality, open access raises several harmful impacts to LLNP not only for ecology but also triggering conflicts among groups of rattan harvesters as well as with LLNP authority. The phenomenon of open access to natural resources is one of the causes of the many failures of natural resource management (Ostrom, 1999). This condition is similar to "the tragedy of the commons phenomenon." Because many parties have taken profit a lot for personal gain rather than distributing it to others, it results in overuse of CPRs. This condition has occurred in LLNP. Hess (2013) found that the rattan population in LLNP decreased significantly due to high volume harvesting. Rattan harvesting will deplete soon if regardless of its ecological sustainability. The sustainability of resources uses requirements, at least, that harvest rate does not exceed the capacity of the populations to replace the individual harvested (Hall \& Baw, 1993).

Previously, the LLNP Office became the single authority in order to manage rattan in its area. Then the policy of park management changes from time to time to accommodate the interests of the stakeholders (Dunggio \& Gunawan, 2009). LLNP Office has initiated collaboration management with a program named Community Conservation Agreement (CCA) since 2001. Co-management has been defined as the sharing of power and responsibility between the government and local resource users (Berkes et al., 1991). Comanagement is considered different from community-based resource management (CBRM) because the government is also involved in the decision-making process of management (Sen \& Nielsen, 1996). CCA was implemented in 26 villages adjacent LLNP. Institutional arrangement of CCA is built from jointing an informal and a formal institution. As an informal institution, the customary institution has customs, taboos, traditional norms, and also rattan ethnobotany. Whereas, LLNP has strict regulation instruments; therefore, establishing a co-management model is a new challenge for ensuring sustainable rattan management. Complex institutional mechanisms and processes dealt with to share management authority and responsibility among a plurality of formally and informally entitled governmental and nongovernmental actors (Dudley, 2008).

Feeny et al. (1990) stated that the degree of CPRs management success was determined by the complex interactions among the characteristics of the resource, the property-rights regime and other institutional arrangements, and the socio-economic environment. However, based on many previous researches, CCA in LLNP faced many problems in its implementations. There are multiple interpretations of the roles, functions, and interpretations of CCA(Ichsan, 2008). Whereas Massiri et al. (2015) found that despite CCA led clarity of users and clarity of resources, however, the rules at the operational level arranged in CCA were not in line with formal rules of national park management at the constitutional level (a nested enterprise problem). Furthermore, the allocations of CCA location were on the rehabilitation zone and utilization zone that become barriers to the sustainability of CCA because that rules do not support the sustainability of the livelihood of local communities. Then, Massiri et al. (2019) also found that the principles of collective-choice arrangements and minimal recognition of rights to organize in CCA were not running well. Recently, LLNP Office has reinitiated CCA with a different name called Community Conservation Partnership (CCP). Therefore, the objective of this study is to explore how to craft local institutions of CCP for sustainable rattan governance in LLNP using Social-Ecological Systems (SES) Framework. SES framework enables the integration of social and ecological systems to include variables in the same depth level and flexibility in choosing relevant variables for resource governance and resource management (Binder et al., 2013).

Moreover, developing the SES Framework is to provide further attention to nature's side of human-nature interactions compare with IAD Framework. However, between SES and IAD framework are very close that they have the central core of analysis in action situation. This study was conducted in Ngata Toro, where it has processed the local institution development of CCP. Ngata Toro is a traditional village that has long experience with ethnobotany of rattan. This knowledge partially regulated in customary law to ensure rattan sustainability and fairness utilization for its communities. It consisted of customs, taboos, traditional norms, and sanction that delivered by oral from generation to generation.

\section{Methods}

The research was conducted in LLNP and Ngata Toro. LLNP was designated as a national park in 1999, which has $217,991.18$ ha area, and its area was revised in 2014, becoming $215.733,70$ ha. While Ngata Toro is located in the LLNP's buffer zone at Kulawi Sub-district, Sigi regency. The co-management site is in the traditional zone that has a 1937.04 ha area. It is located at $\mathrm{S}^{\circ}{ }^{\circ} 29^{\prime} 48.40^{\prime \prime}$ and E120 3'22.90" (Figure 1).

The research was carried out from October 2017 to March 2018. Data was collected through rattan inventory, interviews, and direct field observation. Furthermore, 18 interviews were conducted by purposive sampling, who deliberately selected individuals who thought to have knowledgeable in rattan utilization and management. They are Ngata Toro customary councils, rattan harvesters, rattan craftsmen, and LLNP field officers. The interviews intend to collect rattan ethnobotany and social aspect, i.e., Ngata Toro customary law, traditional land-use system, rattan utilization, customary institution, CCA institution, and others. Rattan inventory was focused on commercial rattans and conducted by stratified sampling in several habitat types. Samples were collected using strip sampling $20 \mathrm{~m} \times 100 \mathrm{~m}$ in which each strip is divided into five plots sizing $20 \mathrm{~m} \times 20 \mathrm{~m}$. Total strip samplings for all park area were 39 units (equivalent to 195 plots, taken data were: rattan species, diameter, height, and fresh weight). Data of rattan standing stock and increment in the traditional zone were interpolated form this total park area.

We use the SES framework (Ostrom, 2009; McGinnis \& Ostrom, 2014) to analyze local institution development of CCP. SES framework is multi-tiered variables consisting of components (first tier), attributes (second tier), and subdimensions of attributes (further tiers) (Figure 2).

The framework enables the integration of social and ecological aspects with equal analytical depth, multi-layered 


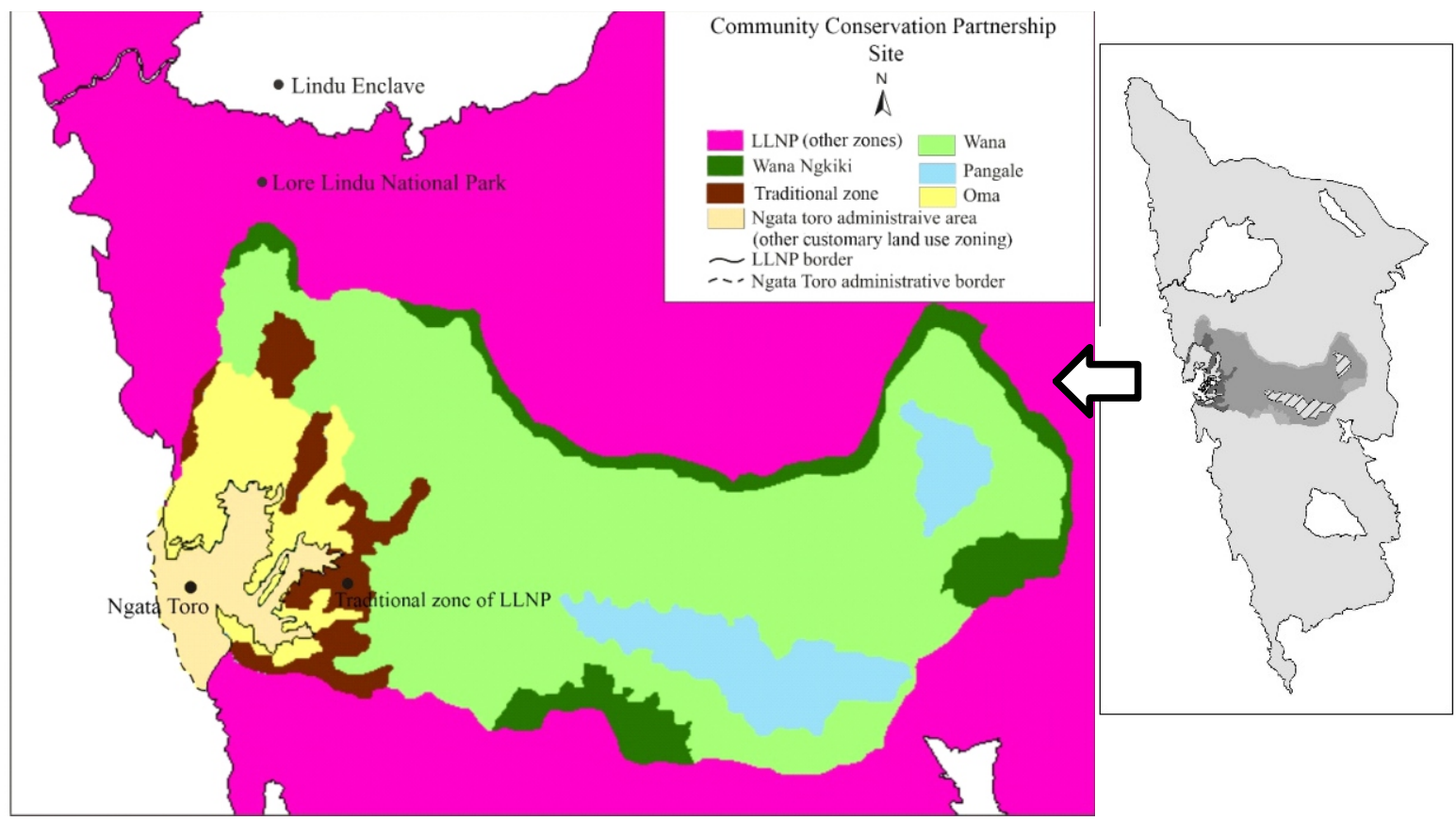

Figure 1 Traditional zone as CPP site and overlapping customary land use zoning of Ngata Toro and LLNP area.

Social, economic, and political (S) setting

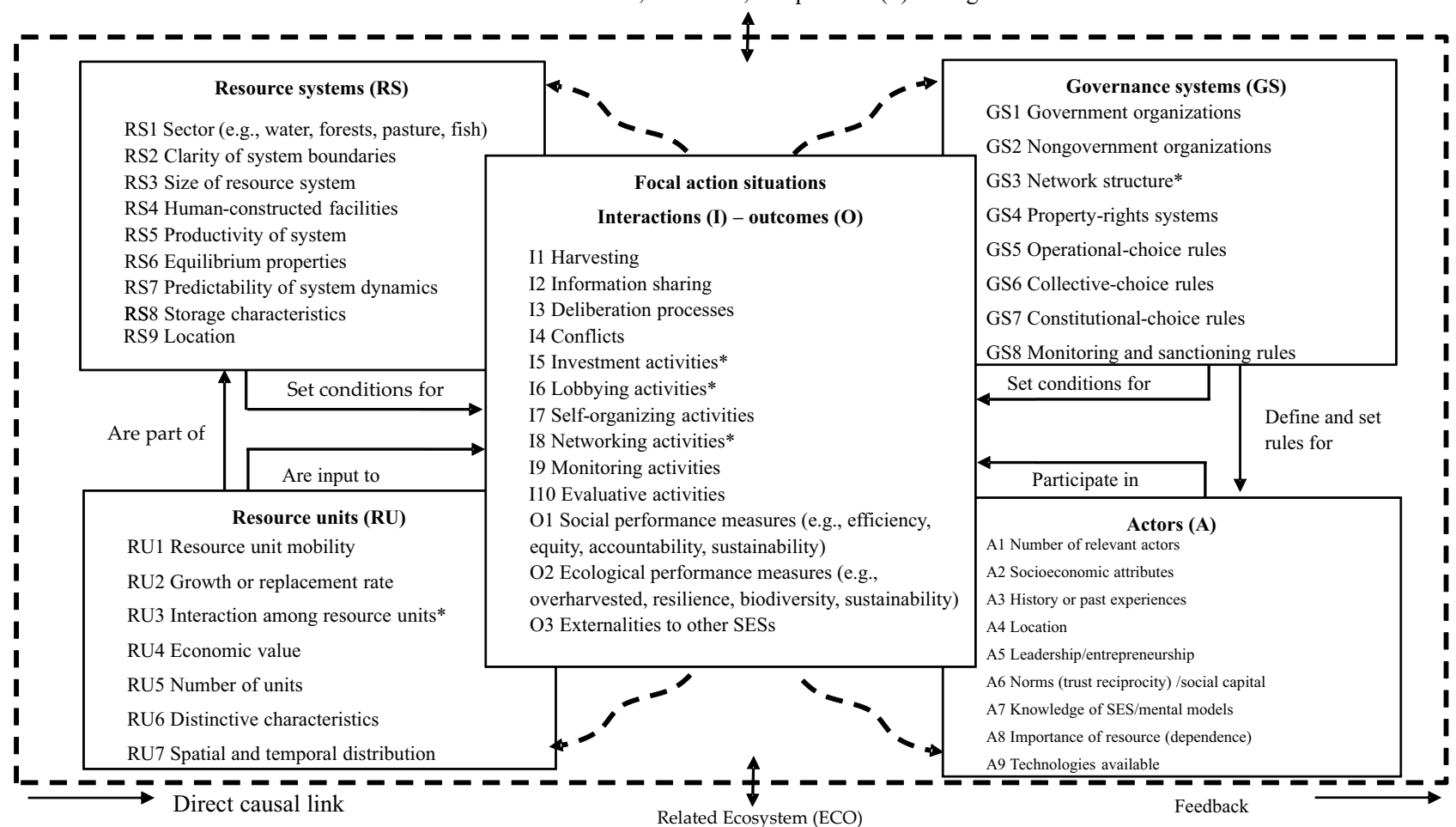

Figure 2 SES framework adapted from Ostrom (McGinnis \& Ostrom, 2014). We focused on five components (resource system, resource units, governance system, actors and focal action situation) and their related attributes to these components. *indicated unrelated attributes for co-management arrangement for rattan governance in LLNP. 
diagnostic procedures of a system, and flexibility in choosing relevant variables. SES framework provides analysis options for selecting the relevant variables to describe the dynamical systems and their interactions and suggests variables for analyzing the potential sustainable development of a socialecological system (McGinnis \& Ostrom, 2014). The social system and ecological system dealt with rattan ethnobotany and rattan population management. We did qualitative analysis from interviewed knowledgeable ethnobotany, and customary law and literature reviewed analysis. Rattan population management was analyzed the dynamic relation among growth or replacement rate, the productivity of the system, economic value, and harvesting quota. We decided rattan harvesting quota on the rattan increment rate. Sustainable harvesting is achieved if annual harvesting is not exceeding the annual increment (Hardjoprajitno, 2000):

$$
\begin{aligned}
& \mathrm{AAC}=I n c \\
& H q=I n c \times 0.8
\end{aligned}
$$

AAC is an annual allowable cut (ton year ${ }^{-1}$ ) that represents the standing volume of harvested rattan. Inc is increment (ton year ${ }^{-1}$ ). It was calculated by considering annual rattan growth, fresh rattan weight, and rattan population in the traditional zone. The annual rattan growth rate referred with previous research and field measurement. Powling (2014) recorded the rattan growth of Calamus ornatus as $0.7 \mathrm{~m}_{\text {year }}{ }^{-1}$, and C. zollingeri has a growth rate of $1.35 \mathrm{~m} \mathrm{year}^{-1}$. Dransfield (1979) in Januminro (2000) found that $C$. inops has a growth rate of 2 to $3 \mathrm{~m}$ year ${ }^{-1}$. Based on the field measurements, we found that the annual growth of Daemonorops macroptera is $1.21 \mathrm{~m}_{\text {year }}{ }^{-1}$. Fresh rattan weight data were collected by weighing average canes of each species and converted in ton $\mathrm{m}^{-1} . \mathrm{Hq}$ is an annual harvesting quota (ton year ${ }^{-1}$ ) that calculated by multiplying Inc with a correction factor. ITTO and MoF (2008) have determined 0.8 as the correction factor for harvestable rattan canes. $\mathrm{Hq}$ is also to estimate the volume of marketable rattan canes. For estimating harvesting quota, we used system dynamics software, Powersim Studio 10, that able to projecting $\mathrm{Hq}$ in many years scenarios Figure 3.

The stock-flow diagram in the system dynamics, Figure 3 , is enabled to calculate sustainable rattan harvesting in certain conditions. Since the Ngata Toro community harvested rattan using a harvesting cycle called ra ombo which usually conducted in 5-year cycles for economic safety nets purpose, accumulation of annual increments is used for deciding accumulative harvesting quota. On the other hand, rattan also has been utilized for subsistence in small quantity; therefore harvesting quota can be set annually (annual harvesting quota).

\section{Results and Discussion}

Bring ethnobotany and ecological knowledge into local institutional development SES framework is multi tiers institutional analyses. Two first-tier concepts related to the ecological system, namely the resource system and resource units, whereas governance systems and actors related to a social system. SES framework conceptualizes the ecological system from an anthropocentric perspective (Binder et al., 2013). Moreover, SES framework enabled bridging communication across the multiple disciplines concerned

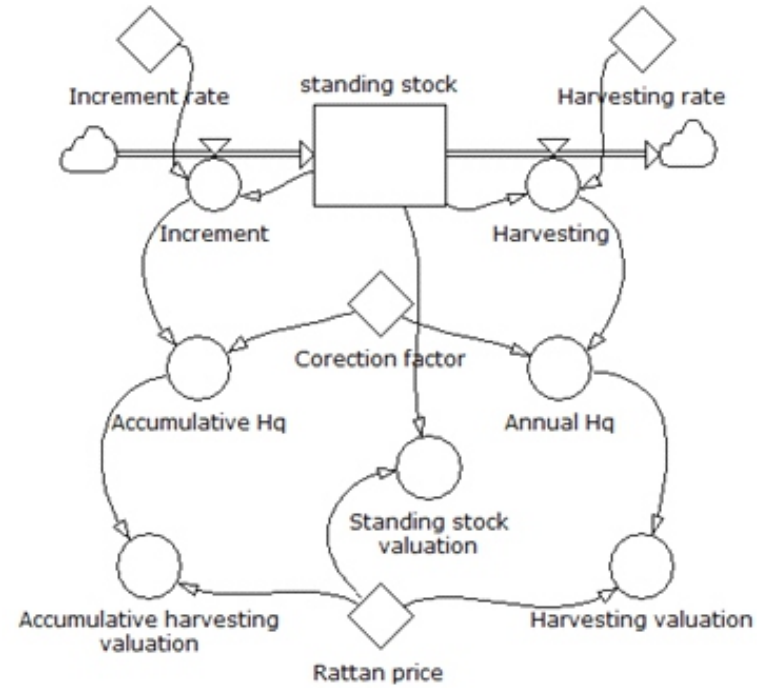

Figure 3 Stock flow diagram model of system dynamics approach for calculating sustainable rattan harvesting in CCP.

with the sustainable provision of common-pool resources (Ostrom, 2009). Traditional knowledge and ecological knowledge are not mutually exclusive; instead of they should be viewed as complementary. Traditional knowledge has a vital role in forest management because it has been believed to be often favorable towards conservation and sustainable use (Pei et al., 2009). Rattan ethnobotany and ecological knowledge are not mutually exclusive, instead, they should be viewed as complement each other. Bridging them, it develops social-ecological understanding and social capital in co-management. It is widely accepted that local communities will be more receptive when their experiences are adopted in resource management. Ngata Toro's customary council has local knowledge such as rattan ethnobotany and customary community law. Whereas, LLNP has regulation and rattan silviculture.

Ngata Toro is remarkably strong traditional institutions in the setting in Central Sulawesi. Local knowledge is perceived as emerging from interactions between the local community and its environment. Some local knowledge and management of rattan were regulated in customary community law. The Ngata Toro manages their land by developing customary land-use zoning i.e., wana ngkiki (restricted forest), wana (primary forest), pangale (primary disturbed forest), pahawa pongko (semi-primer and secondary mixed forest), oma (scrub forest), and balingkea (infertile land)( Mahfud \& Toheke nd). Moreover, customary land-use zoning also related to ownership and utilization purposes (Table 1).

Each customary land-use zoning has specific purposes, level protection, and ownership (Table 1). We identified that this concept could be considered in deciding a traditional zone in LLNP. We proposed several pangale areas that suitable for the traditional zone by considering rattan availability, distance to Ngata Toro settlement, level of 
wildlife conservation interest, and communal property (Figure 1). Traditional zone designation is important in CCP because it is the resource system location in co-management.

Rattan has important roles for subsistence and economic safety net for the Ngata Toro community. Therefore, rattan harvesting is controlled tightly with customary law. It is the informal institution emerging after a long process of them with their natural environment. Community customary law regulates the rotation harvesting period called $\mathrm{ra}$ ombo. When it is opened, the local community is allowed to cut rattan during a definite time. The normal time of opening $\mathrm{ra}$ ombo is roughly a month, but it may be closed early if the local community feels sufficient. Period time between closer ra ombo varies from 5 years to 10 years. In brief, ra ombo is one of the strategies to manage rattan utilization sustainably. The customary community law regulates toipetagi (restrictions) dan toipopalia (taboo) such as the prohibition of hauling rattan irrigation and paddy field. This is relevance in the case of Toro, where most cash income is still obtained from rice production. Another restriction is harvesting rattan in beyond harvesting period time in ra ombo opening. Consequently, violators will be tried and punished by the customary law council.

LLNP used an ecological approach to manage its resources. The most useful strategy to prevent overharvesting is by finding out the growth potential of rattan. If people know the growth, they can use renewable resources sustainably (Dohrenbusch, 2006). Sustainable harvesting can be achieved if we applied a harvesting method that provides a constant supply. For sustainable use, conserving rattan is important. Hamzari (2011) stated that to maintain rattan productivity, rattan farmers shall apply collection principles of selective rattan harvesting and wise use. The rattan inventory on natural forests and cultivated areas aims to estimate standing stock and identify characteristics and ecological requirements of each species concerned, their geographical distribution, their production capacity, and others (ITTO \& MoF, 2008). Standing stock and increment are used to make a planning of sustainable harvesting. Rattan inventory was conducted for many purposes, such as to collect information about rattan diversity, distribution, standing stock, and rattan increment. The prominent commercial rattans in Ngata Toro are batang (C. zollingeri Becc.), tohiti (C. inops Becc.), lambang (C. ornatus var. celebicus Becc), and noko (D. macroptera

Table 1 Rattan utilization in customary land use zoning of Ngata Toro

\begin{tabular}{lll}
\hline Zones & Rattan utilization & Ownership \\
\hline Wana Ngkiki & Forbidden & Communal property \\
Wana & Allowed & Communal property \\
Pangale & Allowed & Communal property \\
Pahawa pongko & Allowed & Communal property \\
Oma & No rattan & Private property \\
Balingkea & No rattan & Private property \\
\hline
\end{tabular}

(Miq.) Becc.) (Table 2).

Between standing stock and increment have a positive causal loop in which if standing stock increases, its increment will increase. The standing stock of rattan at the end of 2017 was 296.02 tons, and its annual increment is projected as 32.93 tons $(11.12 \%)$ (Table 2$)$. After multiplied with the correction factor $(0.8)$, the harvesting quota $(\mathrm{Hq})$ in 2018 is 26.34 tons year ${ }^{-1}$. Ngata Toro community has a harvesting cycle called opening ra ombo in which harvesting usually conducted every five years. Figure 4 showed the scenarios of sustainable rattan harvesting in opening ra ombo in 2022 and annual harvesting.

In the sustainable management, deciding harvesting quota is very important. Rattan has an important role for the Ngata Toro community as an economic safety net during either drought or food shortages occurred, which managed with ra ombo system. Besides economic safety nets, sometimes, it has also been used for subsistence purposes such as housing construction material and customary needs. The previous harvesting for economic safety nets purpose was in 2017; therefore, the next opening ra ombo or rattan harvesting suppose to in 2022. The harvesting quota would be 41.11 tons year ${ }^{-1}$ if the Ngata Toro community did not harvest rattan annually for subsistence. (Figure 4 ). By this harvesting system, the standing stock will increase from 296.02 tons in 2017 to 461.89 tons in 2022. Accumulation of harvesting quota will affect to increase both standing stock and next harvesting quota. Whereas, annual harvesting quota was 26.34 ton year $^{-1}$ as maximum harvesting. However, based on the interview, utilizations for subsistence were in low quantity. If any utilization for subsistence during a year, the standing stock, increment, and harvesting quota for the next year rattan management can be analyzed using the stock-flow diagram model (Figure 3). Because rattan harvesting in Ngata Toro is mostly for economic safety nets, so this discussion emphasized economic safety nets purpose.

Applying the SES Framework in crafting local institutions for sustainable rattan management $\mathrm{CCP}$ is improved from CCA by adopting appropriate components and strengthening the weaknesses. The successful establishment and management of conservation areas require consideration of the specificity of the local context, such as the abundance of forest resources, accessibility, and historical forest-people interactions, in addition to biological factors

Table 2 Rattan standing stock and its increment in traditional zone

\begin{tabular}{lcc}
\hline Habitat types/species & $\begin{array}{c}\text { Standing stock } \\
\text { (ton) }\end{array}$ & $\begin{array}{c}\text { Increment } \\
\text { (ton year }\end{array}$ \\
\hline Lower Montane Forest
\end{tabular}




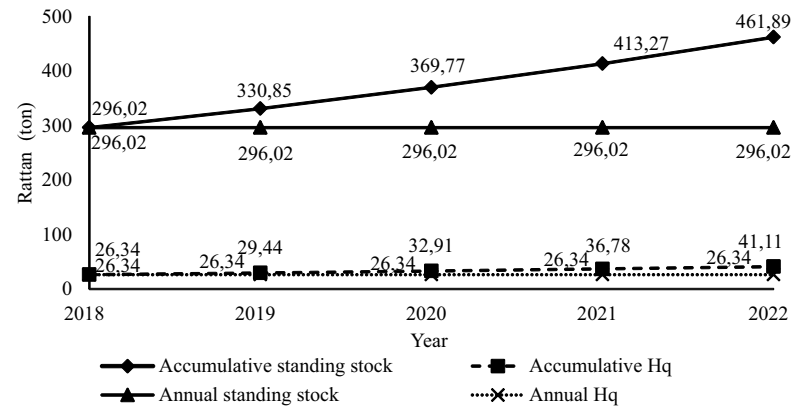

Figure 4 Sustainable rattan harvesting scenarios of CCP in Ngata Toro.

(Widayati et al., 2010). Central to the SES framework is the concept of action situation transferred from the IAD framework. This is where individual actors interact with one another and thereby jointly affect outcomes (McGinnis \& Ostrom, 2014). In developing CCP institutions, the governance system and resource system are set for focal action situations by getting input from rattan as a resource unit and participation from LLNP and customary councils as actors.

Resource system (RS) Resource unit is a part resource system. The resource system of rattan is part of the forestry sector (RS1) in LLNP, innate with the complexity of its social and ecological aspects. CCP attempts to confirm the clarity of system boundaries (RS2) by deciding the concession area in the traditional zone as the legal geographical boundary, arranging institutional choice rules, and transferring property rights. However, the size of the resource system (RS3) is scoped the collaboration of rattan management in the concession area of the traditional zone. CCP excludes rattan governance in broader copes, for instance, rattan trading and market level. LLNP is a conservation area; however, it is minimalized human-constructed facilities (S4). The anthropogenic facilities are necessarily provided, including zoning border markers, rattan nursery, and footpath. Rattan productivities (S5) is called increment. Rattan increment rate depends on population standing stock, habitat support, and its biological characteristics. Managing rattan deal with equilibrium properties (RS6) of rattan standing stock, which influenced by increment rate and harvesting rate. If the harvesting rate is higher than the increment rate, rattan production will deplete. Balancing harvesting rate and increment rate trough quota harvesting is a mechanism to conserving rattan. Rattan is a stationary resources unit; therefore, predictability of system dynamics (RS7) is more predictable compared with a non-stationary unit resource like fish in the ocean. Rattan inventory is a method for collecting data of the rattan population for sustainable management planning. Several system dynamics software can be used for calculating standing stock and harvesting quota. Standing stock of rattan should be maintained or increased for ecosystem balancing. The dynamic system software enables us to $b$ predict storage characteristics (R8).

Resources system location (RS9) of CCA previously was allocated in rehabilitation and utilization zone. However, these zones did not have rattan standing stock because the rehabilitation zone is encroachment and open area, whereas the utilization zone addressed for tourism facilities. Then, in CCP, it was revised by allocating in a traditional zone. A traditional zone is an area that used traditionally by local communities to harvest rattan and other non-timber forest products. In addition, the concession area is proposed as 1,937.04 ha of in the traditional zone of LLNP. The smaller and more clearly denned the boundaries of the common-pool resources, the higher the chances of success (Wade, 1987). LLNP's traditional zone is allocated in an area with less conservation value and has a high interaction of Ngata Toro Community.

Resource units (RU) Rattan is classified as a stationary resource unit (Ru1). This physical characteristic has an impact on management because of their relationship on how to manage information (Blomquist et al., 1994). Comparing mobile resource unit, the spatial distribution of the stationary resource unit is easier to be recorded and mapped for management purposes. Therefore, rattan can be calculated its standing stock and potential growth using inventory. Ngata Toro community has a harvest cycle called ra ombo. This tradition rule should be improved by deciding a harvesting quota for ensuring sustainable harvesting. Rattan sustainability could be achieved if harvesting could not exceed its increment rate or replacement rate (RU2). Based on the rattan inventory, the increment rate is 11.12 percent from standing stock and the rattan accumulative harvesting quota in 2022 is 41.11 ton year ${ }^{-1}$. Its economic value (RU4) is equal with IDR 49,332,000 by the current rattan price IDR1,200,000 ton ${ }^{-1}$. Compared to other NTFPs, harvesters could easily generate a cash income by selling rattan in as raw material. Amount income depends on the rattan price, increment rate, and concession area. Besides economics values, rattan has indirect values, i.e., cultural, ecological, and conservation values. The number of units (RU5) or standing stock is 461.89 tons in 2022 if only harvesting for economic safety nets.

Rattan inventory has high difficulties due to its distinctive characteristics (Ru6). As climbing plat, rattan cannot grow straight up. It needs a tree as host to attach its canes using its flagella or cirrus. In addition, rattan grows mostly in clustering and has spines in its leaf sheath and leaves. C. zollingeri, C. ornatus, and D. macroptera are life in clustering, whereas $C$. inops is solitary rattan. $C$. inops is more vulnerable due to its regeneration only depend on its seeds. Furthermore, rattan has various spatial distribution but unclear of temporal distribution (RU7). In the traditional zone, C. zollingeri, C. inops, C. ornatus and D. macroptera are found in lower montane forest, whereas $C$. inops found in upper montane forest.

Actors (A) CCP is set for co-management between relevant actors in rattan governance in LLNP. The relevant actors (A1) are LLNP office and customary councils (Lembaga adat) of Ngata Toro. Customary councils represent of Ngata Toro community who is living in Toro Village. Whereas the structure of CCP consists of the representative members, both relevant actors called CCP councils. LLNP office has 
the main office in Palu City and also resort Office in Toro that same location (A4) with Ngata Toro's customary councils. Institutions operate intimately intertwined with the human, social, and biophysical contexts (Anderies et al., 2016). Socioeconomic attributes (A2) of the Ngata Toro community can be explained based on its population size, livelihood, and its informal institutional local custom. Ngata Toro has population of 2,460 people, and 602 households who are living depend on agriculture as the main income. Rattan is one of the most important NTFPs for Ngata Toro Community. It has functioned as an economic safety net during the drought and crop failure. Ngata Toro customary law is the local wisdom based on past experiences (A3). Local communities who have lived close to the forests for a long time often have useful forest knowledge based on their long term, local experience (Purnomo et al., 2004). Different from common communities, Ngata Toro Community is not chaired by a single person, but by principal components of customary councils namely Maradika, Totua Ngata, and Tina Ngata (Mahfud \& Toheke, 2003). Their leadership (A5) has important roles in influencing the community. They have certain different responsibilities in managing social and natural resources management in their customary land. All the lands of Ngata Toro are the communal property called huaka. Whereas, a private property called dodoha is only for people who are first converting the forest land to agricultural land (pampa). Collective rattan management is a social capital (A6) that has been suggested as a potentially useful approach for reducing inequality, open access and overharvesting. To get a good local alignment, one needs to build trust and reciprocity among members so they can sustain collective action in the face of social dilemmas (Blomkvist, 2013). Ngata Toro community has high dependence (A8) with rattan. Rattan is an important unit resource for Ngata Toro communities. Besides cash income, rattan canes used for many purposes, such as material for traditional house Lobo and Tambi, furniture, and ties. Rattan shoots are used for a banquet in important ceremonies. Two actors in comanagement bring their own different knowledge (A7) in CCP. Ngata Toro Community council brings traditional and simple technology in harvesting, transporting, and less technology (A9) for rattan processing. Rattan silviculture and simple final rattan processing were readily introduced by LLNP in several different locations.

Governance system (GS) Developing CCP institution is addressed to the co-management between LLNP office representing the central government (GS1) as the owner of the resources and customary councils represent of Ngata Toro community (GS2) as users of the resource. The previous institution of CCA was regardless of property-rights transfers; therefore there are problems in the implications. The function of the property-rights system (GS4) is to legitimacy the resource unit governance and another also for the exclusion of non-Ngata Toro community's members. In co-management, boundaries of rules should be clearly defined. Operational-choice rules (GS5) regulate who can lawfully get access, what mechanism they must take, how much the harvesting quota, and what kind of tools are permitted. Operational rules are changed by collective- choice actions (Schlager \& Ostrom, 1992). The middle level, Collective-choice rules (GS6) regulate who can make or modify operational rules arid under what conditions. Different types of organizations will be responsible for crafting different kinds of rules (McGinnis \& Ostrom, 2014). Constitutional-choice rules (GS7) are exclusively owned by the central government agency that executed by LLNP as its representative at the local level. The rules stated in the government decree or ministry of forestry decree that regulated what powers and authority they can share among co-management actors, membership rules and guidelines for creating the lower-level rules. Previously, it becomes one of the reasons why CCA in 26 villages unsuccessful their implementation due to unclear of nested enterprise in which among many levels of choice rules un-linkage. Recently, there many new regulations regarding co-management in a conservation area that could strengthen local institutional development, for instance, the Regulation of the Minister of Environment and Forestry Number P.43/MENLHK/ Setjen/Kum.1/6/2017, local communities can be given access to utilize NTFPs within the traditional zone by collaboration management or co-management. Then, it has been strengthened by Directorate General of Natural Resources and Ecosystem Decree Number P.6/KSDAE/SET/ Kum.1/6/2018 regarding the technical guidance of conservation partnership in nature reserve area and nature conservation area. These constitutional-choice rules necessary and become a strong foundation for establishing CCP in Ngata Toro. The concept of this nested enterprise enables CCP to be implemented without any contradiction rules as previous CCA implementation.

The success of implementation is also depended on their monitoring and sanctioning rules (Gs8). Monitoring is done using several tools such as field survey (joint monitoring), rattan inventory, and land cover analysis. Whereas, gradual sanction for violators will be tried and punished by the customary law councils of Ngata Toro and possible to be directed in formal law. Peer monitoring and punishment is an important means to mitigate free-riding in social dilemmas (Shreedhar et al., 2018). Violators will be tried and punished by the customary law council, and they will be fined with Tolu Ongu (3 buffalos or cows), Tolu Mpulu (30 dulang), and Tolu Tigkau (30 sheets of Mbesa fabric).

Focal action situations Ngata Toro community has utilized rattan as the important unit resources from LLNP. Rattan from LLNP has been harvested by the Ngata Toro community for subsistence and economic safety net purposes. Regulating rattan harvesting (I1) is an important key in sustainable rattan management. The harvesting quota is decided based on its increment growth. They are harvesting mostly for economic safety nets using ra ombo system. If any harvesting for subsistence harvesting quota should be evaluated and recalculate for next harvesting planning. The harvesting quota, number of harvesters, and harvesting sites should be clearly stated in operational-choice rules. These rules were established from information sharing (I2) between relevant actors who share their knowledge. Ngata Toro has rattan ethnobotany, while LLNP can share ecological knowledge in terms of deciding harvesting quota, planting 
rattan, and others. Knowledge of a customary community is locally, specifically, and adaptively with its environment showed that natural resources should be managed based on their characteristics (Kosmaryandi et al., 2012). The resilience will support each other if the authority of natural resources is not top-down, and common management should be adopted from the characteristics of the local natural resources (Khan, 2008). CCA needs six years negotiation and deliberation process until established in 2007. However, CCP will be a smooth deliberation process (I3) because it will be developed from CCA institution. Co-management can be examined as a problem-solving process involving negotiation, deliberation, knowledge generation, and joint learning (Berkes, 2009). In several level choice rules developments, the deliberation process only enables for operational choice rules and collective-choice rules. In creating operational choice rules, it is needed more attention from both actors. Operational choice rules regulate many specific and crucial aspects of governing rattan whereas constitutional-choice rules are the domain of Ministry of Environment and Forestry.

One of the aims of CCP establishment is to reduce conflicts (I4) among users and with LLNP office. The last conflict occurred at the end of 2017 when several harvesters cut rattan from the forest outside allowable period ra ombo. Conflict among community members is solved in the village level using its local law, conflicts among villages will be mediated by LLNP and buffer zone forum, and conflict will be resolved in formal law as the last option. The violators were adjudicated by the customary council and give a punishment. This was evident that local customary law has a strong power in the community. They have a special traditional house called lobo for conducting important meetings. When the Ngata Toro community was unable to resolve the internal conflict, the issue was taken to court depend on on-site location of the violation. If it happens in LLNP area, LLNP forest rangers and investigators will overtake the cases. Self-organizing activities (I7) is dealt with internal rules for the extraction and management of resources among users (Delgado-Serrano \& Ramos, 2015). It related to technical rules at the local level, i.e., harvesting periods, restocking period, harvesting harvester selection, harvesting equipment, and harvesting technique. Based on Directorate General Decree of Natural Resources and Ecosystem Number P.6/KSDAE/SET/Kum 1/6/2018 in article 38, monitoring activities (I9) in co-management at least done every six months. Monitoring activities consist of a field survey called joint monitoring between forest rangers of LLNP and Ngata Toro customary councils. Whereas rattan inventory and land cover analysis are conducted and analyzed by LLNP's staff. Besides monitoring, evaluation activities (I10) are important steps for improving CCP implementation. Evaluation involves collecting and analyzing information about the CCP activities and their outcomes.

The institution's development aimed to generate benefit from both social and ecological outcomes. The benefit of $\mathrm{CCP}$ can be measured by improving social performance (O1). CCP should bring efficiency in LLNP management, high accountability, and ensure income sustainability. Joint smart patrol between customary councils and LLNP's rangers will reduce exclusion costs. Moreover, harvesting planning, monitoring, and reports will increase management accountability and increase trust among relevant actors. Furthermore, it not only calculating the amount of sustainable harvesting with the previous method as indicator environmental performance $(\mathrm{O} 2)$ but also need to maintain biodiversity in rattan habitat. Managing rattan in the traditional zone gives externalities to other SESs (O3). Besides rattan, other small unit resources such as copal, bamboo, medicinal plants, forest honey, and others will be managed due to becoming part management concerns of institution CCP development.

Property rights transfer For effective co-management, particularly the conditions that property rights should be secure and well-defined, transferred appropriate and sufficient powers to communities and developed local institutions (Ribot, 2002; Larson \& Ribot, 2004). The transfer of rights aims to determine the position and responsibility of the parties in forest management. Therefore, it is necessary to consider the extent to which individuals obtain benefits together by minimizing the existence of free riders that is a problem in the use of CPRs. Schlager \& Ostrom (1992) classified property-rights regimes into access and withdrawal, management, exclusion, and alienation rights. Property-rights regimes of CCP were shown in Figure 5.

Access and withdrawal rights are granted to communities for harvesting rattan limited in their concession area in the traditional zone. Management rights of rattan in the traditional zone are partially transferred to the Ngata Toro community in CCP, and several management actions still under LLNP's decision. Harvesting quota is decided by LLNP Office based on ecology analysis as well as the number of harvesters. However, other management decisions can be worked together, for instance, planning,

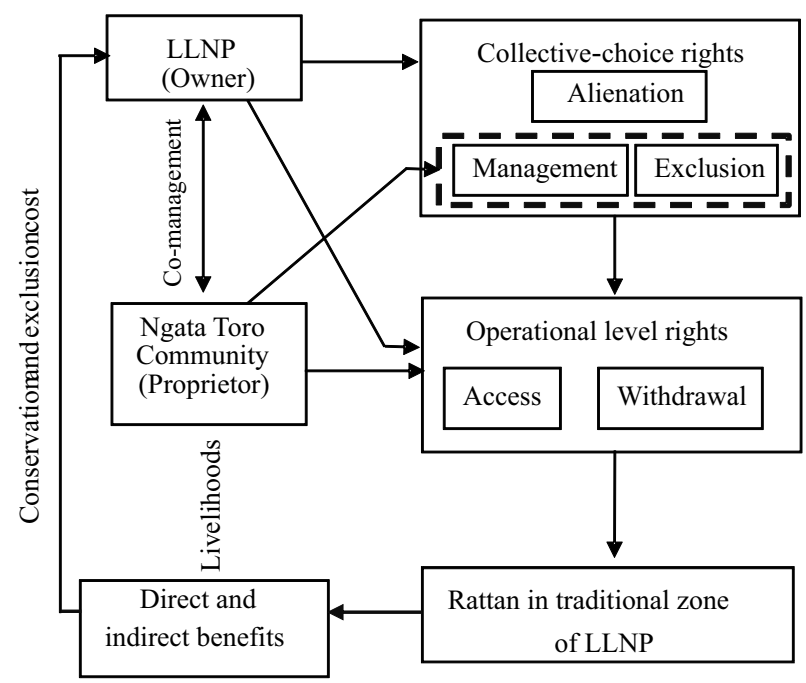

Figure 5 Property rights regimes of CCP for governing rattan in LLNP (modified from SIKOR et al. (2017)). 
monitoring, and evaluation. CCP councils should able to manage themselves. It implies that they have the right to decide the community member who has access to harvest rattan and who has not from the concession area. This exclusion right is important to prevent free riders from both inside and outside communities. Alienation rights are not transferred to the community in CCA to prevent management problems. The position of CCP councils of Ngata Toro related to the bundle of rights is a proprietor. Proprietors authorize who may access resources and how resources may be utilized; however, they do not have the right to alienate either of these collective choice rights (Schlager \& Ostrom, 1992). The relationship of trustees (principals-agents) in comanagement greatly determines the success of forest resource management.

As we argue above, CCP in Ngata Toro will bring many benefits for the local community and LLNP Office. CCP will increase the legitimacy of the Ngata Toro Community in managing rattan because there are transfer property rights (Gs4), for instance, access and withdrawal, management, and exclusion at certain levels from LLNP Office. Ngata Toro community has past experiences (A3) for an extended period in rattan governance using customary law. It will reduce monitoring and exclusion cost for LLNP. Institutional strengthening is the effort to reorganize or reorient institutions to enable them to become more effective functions (Hammergren, 1998). It is reducing conflict among communities also with LLNP with clearing the boundary and rules. Increasing rattan suitability production $(\mathrm{O} 2)$ with the implementation of quota harvesting and ra ombo system. It also enables us to sustain (O1) the Ngata Toro Community livelihood

\section{Conclusion}

The SES framework is strongly useful in crafting CCP institution of Ngata Toro for governing rattan in the traditional zone of LLNP. We argue that strengthening the local institution of CCP is most likely to be successful due to several reasons. Firstly, the current establishment of constitutional-choice rules is fit with operational and collective choice rules in the concept of nested enterprise. Secondly, we suggested adopting customary community law, rattan ecology knowledge, and government regulations in developing the operational-choice rules of CCP. Thirdly, the designation of the traditional zone of LLNP as the CCP location makes the resource system boundary. Fourthly, the position of Ngata Toro Community in $\mathrm{CCP}$ is the proprietor in which access and Withdrawal, Management, and Exclusion right are transferred from LNP Office. It makes effective co-management, increases the legitimacy of rattan utilization, decreases potential conflicts among resource unit users, and reduces monitoring costs for the LLNP Office. Moreover, this analysis results also demonstrated that developing CCP using SES framework in line with congruence concepts of Ostrom, namely the congruence with the local ecology, local culture, and between benefits and costs in governing the commons. In general, the SES framework provided variables that capable of broadly laying out relevant aspects of crafting local institutions of CCP for sustainable rattan management in LLNP. However, the challenging of this framework is apparently in the implementation would need the depth analyses of broad ranges of influential variables by involving many methods. For expanding programs, the variability of community attributes and the resource unit size will be the common challenges in developing CCP in other communities surrounding LLNP. Further research may be suggested to investigate the impacts of the CCP implication using SES framework toward rattan sustainability, national park management, and social aspects of communities.

\section{Acknowledgment}

The authors wish to express gratitude to the leaders and staff of LLNP for permission, assistance, and facilities during the research activities performed in the field; to the local communities of Ngata Toro, the head and staff of the biodiversity laboratory of Tadulako University who help in the identification process.

\section{References}

Anderies, M. J., Janssen, M. A., \& Schlager, E. (2016). Institutions and the performance of coupled infrastructure systems. International Journal of the Commons, 10(2), 495-516. https://doi.org/ $10.18352 / \mathrm{ijc} .651$.

Barrios, J. C. H., Anten, N. P. R., \& Ramos, M. M. (2014). Sustainable harvesting of non-timber forest products based on ecological and economic criteria. Journal of Applied Ecology, 52, 389-401. https://doi.org/10.1111/ 1365-2664.12384

Berkes, F., George, P., \& Preston, R. (1991). Comanagement: the evolution of the theory and practice of joint administration of living resources. Paper presented at The Second Annual Meeting of IASCP University of Manitoba, Winnipeg, Canada, September 26-29.

Berkes, F. (2009). Evolution of co-management: Role of knowledge generation, bridging organizations and social learning. Journal of Environmental Management 90, 1692-1702. https://doi.org/10.1016/j.jenvman. 2008.12.001

Binder, C. R., Hinkel, J., Bots, P. W. G., \& Pahl-Wostl, C. (2013). Comparison of frameworks for analyzing socialecological systems. Ecology and Society, 18(4), 26. https://doi.org/10.5751/ES-05551-180426

Blomkvist, P. (2013). An analytical framework for commonpool resource-large technical system (CPR-LTS) constellations. International Journal of the Commons, 7(1), 113-139. https://doi.org/10.18352/ijc.353

Blomquist, W., Schlager, E., \& Tang, S. Y. (1994). Regularities from the field and possible explanations. In Rules, Games \& Common-pool Resources. Ostrom, E, Gardner R, Walker J, eds. Ann Arbor: University of Michigan Press.

Burkard, G. (2007). Two Types of “desa”: Community 
Representation Communal Identity and Property Relation in the Kulawi Valley, Central Sulawesi, Indonesia. Palu, Indonesia. Discussion Paper Series No. 19, Research Project on Stability of Rain Forest Margins (STORMA).

Delgado-Serrano, M. D. M., \& Ramos, P. A. (2015). Making Ostrom's framework applicable to characterize social ecological systems at the local level. International Journal of the Commons, 9(2), 808-830. https://doi.org/10.18352/ijc.567

Dohrenbusch, A. (2006). Forest management systems and diversified production - principles of sustainable management of renewable resources. Paper presented at Sino-german Symposium 2006: The sustainable harvest of non-timber forest products in China. Strategies to balance economic benefits and biodiversity conservation. Beijing: The Sino-German Center for Research Promotion.

Dransfield, J. (1974). A short guide to rattans. Bogor: BIOTROP

Dudley, N. (ed.). (2008). Guidelines for applying protected area management categories. Gland: International Union for Conservation of Nature (IUCN). Retrieved from https://portals.iucn.org/library/sites/library/ files/documents/PAG-021.pdf https://doi.org/10.2305/ IUCN.CH.2008.PAPS.2.en

Dunggio, I., \& Gunamawan, H. (2009). An overview on the history of national park management policy in Indonesia. Jurnal Analisis Kebijakan Kehutanan, 6(1), 43-56.

Feeny, D., Berkes, F., McCay, B.J., \& Acheson, J.M. (1990). The tragedy of the commons: Twenty-two years later. Human Ecology, 18(1),1-19. https://doi.org/10.1007/ BF00889070

Hall, P., \& Baw, K. S. (1993). Methods to assess the impact of extraction of non-timber tropical forest products on plant populations. Economic Botany, 47, 234-247. https://doi.org/10.1007/BF02862289

Hammergren, L. (1998). Political will, constituency building, and public support in rule of law programs. Center for Democracy and Governance Bureau for Global Programs, Field Support, and Research U.S. Agency for International Development.

Hamzari. (2011). Community-based sustainable rattan conservation: A case study in Lore Lindu National Park, Central Sulawesi. Biodiversitas, 12(4), 241-245. https://doi.org/10.13057/biodiv/d120410

Hardjoprajitno, S. (2000). Role of forest survey and mapping in maintaining forest sustainability as an input to regional autonomy. Globe, 2(1), 613 .

Hess, B. (2013). Simulation of rattan harvests in Indonesia.
Different harvesting pressures and the resulting patterns [thesis]. Sweden: Swedish University of Agricultural Sciences.

Ichsan, A. C. (2008). Prospects and challenges of community conservation agreements in the Lore Lindu National Park [thesis]. Bogor: IPB University.

[ITTO] International Tropical Timber Organization, [MoF] Ministry of Forestry. (2008). Technical report: inventory of rattan sanding stock in natural forest and plantation. Jakarta: ITTO and MoF of Indonesia.

Januminro. (2000). Potency of Indonesian rattan, cultivation, processing, quality standards, and the prospects of administration. Yogyakarta: Penerbit Kanisius.

Khan, A. (2008). A solution alternative on law and regulations problem: A lesson of institutional arrangement. Jurnal Manajemen Hutan Tropika, 14(1), $47-53$.

Kosmaryandi, N., Basuni, S., Prasetyo, L. B., \& Adiwibowo, S. (2012). New idea for national park zoning system: A synthesis between biodiversity conservation and customary community's tradition. Jurnal Manajemen Hutan Tropika, 18(2), 69-77. https://doi.org/10.7226/ jtfm.18.2.69

Larson, A. M., \& Ribot, J. C. (2004). Democratic decentralization through a natural resource Lens: An introduction. European Journal of Development Research, 125. https://doi.org/10.1080/09578810 410001688707

Mahfud, R., \& Toheke, R. P. (2003). Customary community of Adat Ngata Toro, Central Sulawesi. In: Kleden, E.O., Chidley, L., Indradi, Y., editor. Forest for future: Indigenous Forest Management in the Middle of a Changing World. Jakarta: Aman-DTE.

Massiri, S. D., Nugroho, B., Kartodihardjo, H., \& Soekmadi, R. (2015). Institutional sustainability barriers of community conservation agreement as a collaboration management in Lore Lindu National Park. Jurnal Manajemen Hutan Tropika. 21(3), 147-154. https://doi.org/10.7226/jtfm.21.3.147

Massiri, S. D., Nugroho, B., Kartodihardjo, H., \& Soekmadi, R. (2019). Institutional sustainability of a community conservation agreement in Lore Lindu National Park. Forest and Society, 3(1), 64-76. https://doi.org/ 10.24259/fs.v3i1.5204

McGinnis, M. D., \& Ostrom, E. (2014). Social-ecological system framework: Initial changes and continuing challenges. Ecology and Society, 19(2), 30. https://doi.org/10.5751/ES-06387-190230

Ostrom, E. (1999). Private and common property. Retrieved from http://encyclo.findlaw.com/2000 book.pdf. 
Ostrom, E. (2009). A general framework for analyzing sustainability of social-ecological systems. Science, 325, 419-422. https://doi.org/10.1126/science.1172133.

Pei, S., Zhang, G., \& Huai, H. (2009). Application of traditional knowledge in forest management: Ethnobotanical indicators of sustainable forest use. Forest Ecology and Management, 257, 2017-2021. https://doi.org/10.1016/j.foreco.2009.01.003

Powling, A. (2004). Rattan: taxonomy and ecology. Indonesia Institute of Sciences (LIPI).

Purnomo, H., Mendoza, G. A., \& Prabhu, R. (2004). Model for collaborative plan of community managed resources based on qualitative soft systems approach. Journal of Tropical Forest Sciene, 16(1), 106-131.

Ribot, J. (2002). Democratic decentralization of natural resources: Institutionalizing popular participation. Washington, DC: World Resources Institute. https://doi.org/10.1057/9781403981288_6

Schlager, E., \& Ostrom, E. (1992). Property-rights regimes and natural resources: A conceptual analysis. Land Economics, 68(3), 249-262. https://doi.org/ $10.2307 / 3146375$

Sen, S., \& Nielsen, J. R. (1996). Fisheries co-management: A comparative analysis. Marine Policy, 20(5), 405-418. https://doi.org/10.1016/0308-597X(96)00028-0

Shreedhar, G., Tavoni, A., \& Marchiori, C. (2018). Monitoring and punishment networks in a common pool resource dilemma: experimental evidence. Centre for Climate Change Economics and Policy Working Paper No. 327 ISSN 2515-5709. Grantham Research Institute on Climate Change and the Environment Working Paper No. 292 ISSN 2515-5717 (Online). Retrieved from http://www.uh.edu/ nfelt/papers/ belief.pdf.

Sikor, T., He, J., \& Lestrelin, G. (2017). Property rights regimes and natural resources: A conceptual analysis revisited. World Development, 93, 337-349 https://doi.org/10.1016/j.worlddev.2016.12.032.

Wade, R. (1987). The management of common property resources: collective action as an alternative to privatization or state regulation. Cambridge Journal of Economics, 11, 95-106. https://doi.org/10.1093/ oxfordjournals.cje.a035024

Widayati, A., Jones, S., \& Carlisle, B. (2010). Accessibility factors and conservation forest designation affecting rattan cane harvesting in Lambusango Forest, Buton, Indonesia. Human Ecology, 38(6), 731-746. https://doi.org/10.1007/s10745-010-9358-7 